\title{
Validated Methods of Cough Assessment: A Systematic Review of the Literature
}

\author{
Sophie Leconte Delphine Ferrant Valérie Dory Jan Degryse \\ Institut de Recherche Santé et Société, Centre Académique de Médecine Générale, Université catholique de \\ Louvain, Bruxelles, Belgique
}

\section{Key Words}

Cough, assessment, monitoring, measurement •

Quality of life - Systematic review $\cdot$ Visual analogue scales

\begin{abstract}
Background: Cough is a common symptom for which patients often seek medical advice and consume vast amounts of drugs. It is a real challenge for both the physician and the clinical researcher to evaluate a cough's clinical importance and its precise response to treatment. Objectives: This systematic literature review has the following objectives: first, to make an inventory of the validated tools for assessing cough, and second, to investigate the extent to which the results of various assessment methods can be correlated. Methods: Two independent investigators searched the Medline, Embase, and Cochrane databases for validation studies on cough assessment tools. Results: Thirty-four studies were included. Several ambulatory cough monitors automatically identify cough and have been validated in a limited number of patients. Three cough-specific quality-oflife scales (Leicester Cough Questionnaire, Cough Quality of Life Questionnaire, and Burden of Cough Questionnaire) have been validated. No validation studies of descriptive scores or visual analogue scales were found. The correlations between quality-of-life scores and cough frequency were good. The correlations between descriptive scores or visual
\end{abstract}

analogue scales and more objective methods, such as cough frequency monitoring or quality-of-life scores, were inconsistent. Conclusion: Cough-specific quality-of-life questionnaires can provide valid outcomes for research into cough. Although the current developments in cough monitoring devices are promising, further studies on a larger scale, under more realistic conditions, and for different patterns of cough are required before they can be recommended for widespread use.

Copyright $\odot 2010$ S. Karger AG, Basel

\section{Background}

Acute cough is the commonest reason for consultation in general practice [1], and persistent cough is the commonest reason for consulting a respiratory specialist [2]. Therefore, cough is undoubtedly a part of many clinicians' daily practice. Evaluating the severity of the cough and its impact on the patient's life is a key step in the clinical work-up of cough. This initial assessment is likely to influence the clinician's decision to prescribe cough suppressants. Cough suppressants are widely used for both acute and chronic cough despite a lack of evidence of their effectiveness [3]. In clinical trials, the effects of various cough suppressants have usually been no better than that of the placebo [4-8]. However, the outcome

\section{KARGER}

Fax +4161306 1234

E-Mail karger@karger.ch

www.karger.com
(C) 2010 S. Karger AG, Basel

0025-7931/11/0812-0161\$38.00/0

Accessible online at:

www.karger.com/res
Sophie Leconte

Institut de Recherche Santé et Société, Centre Académique de Médecine Générale

Université catholique de Louvain

30 Clos Chapelle-aux-Champs bte 3005, BE-1200 Brussels (Belgium)

Tel. +32 2764 3467, Fax +32 2764 3435, E-Mail sophie.leconte@ uclouvain.be 
measures in these studies have frequently been based on patients' subjective evaluations of their cough using descriptive questionnaires or visual scales. The validity of these measures is unknown. Therefore, the evaluation of cough by validated methods is a challenge for researchers and clinicians alike.

The validity of a measurement instrument is the extent to which it measures what it intends to measure [9]. Therefore, the first issue in cough assessment is to clarify what precisely should be measured. Indeed, the assessment of cough severity can involve several different aspects: (1) the importance of the cough, objectively measured in terms of the frequency or intensity of the expulsive effort; (2) the impact of the cough on the patient's quality of life, and (3) the importance of the cough, as perceived by the patient. The following assessment tools are currently available: cough monitors used to objectively measure cough frequency, and quality-of-life questionnaires, verbal descriptive scores (VDS), and visual analogue scales (VAS) used to subjectively measure cough severity. In this paper, we consider these 3 facets of cough assessment (fig. 1).

The main objective of this systematic review of the literature was to identify the existing validated cough evaluation methods. The second objective was to assess their concurrent validity by investigating the ways in which the results of various cough evaluation methods correlate with one another.

\section{Methods}

\section{Search Strategy}

In accordance with our search strategy (online suppl. material, www.karger.com/doi/10.1159/000321231), we searched the entries in the Medline, Embase, and Cochrane Central Register of Controlled Trials databases up until January 26, 2009. The search queries included the MeSH (Medical Subject Headings of the United States National Library of Medicine) term 'cough' as the conditional term, together with all the MeSH terms covering the various cough outcomes encountered during an initial nonsystematic literature search.

\section{Study Selection}

Inclusion Criteria

The criteria were developed according to the objectives of the review.

(1) Validation studies of the objective measurements of cough intensity and/or frequency: any study that compared a specific cough frequency monitoring method with a cough frequency measurement using either video or audio recordings of coughing human beings, with no restrictions in terms of etiology, age of the patient, setting, or treatment of the cough. Randomized controlled trials using several outcome measures, 1 of

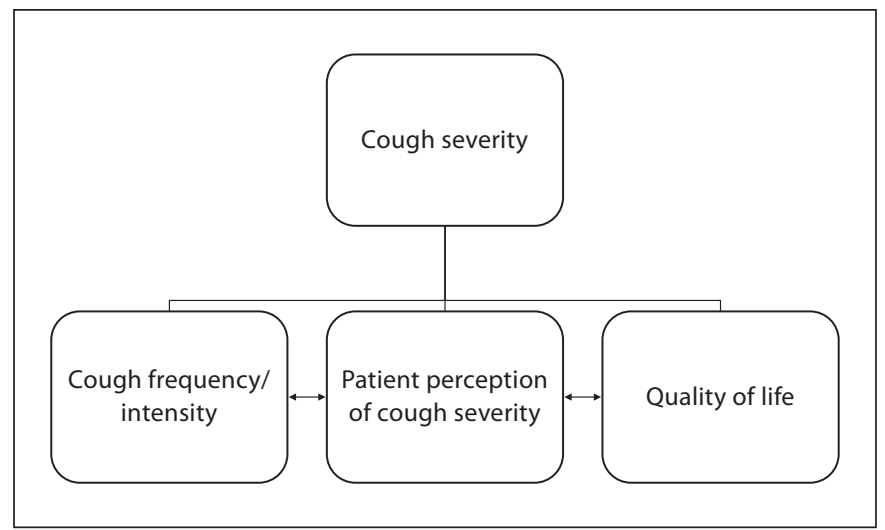

Fig. 1. Cough assessment. There are different cough assessment tools designed to measure different aspects of cough severity, cough frequency or intensity, the repercussions of cough on the daily life of the patients, and the patients' perception of their cough severity.

which was an objective measure of cough intensity and another a previously validated test or scale (e.g. Smith et al. [10] studied the effects of codeine with VAS, VDS, and cough frequency monitoring), were also included because they allowed a comparison to be made between the 2 outcome measures.

(2) Quality-of-life scores or scales: studies that reported their item generation methodology, internal consistency, reproducibility, concurrent validity compared with validated generic quality-of-life scales, and/or responsiveness to change.

(3) Studies pertaining to the reproducibility of descriptive scores or scales assessing cough severity.

(4) Studies that compared the different measurements with validated measurements: studies which used different methods of cough assessment and evaluated correlations between the results of each measurement. We elected to include studies that used objective cough frequency measurements that had only been validated for nighttime use even though we felt that a 24 hour validation would have been preferable.

\section{Exclusion Criteria}

(1) Coughing was evaluated over a short period of time, e.g. immediately after a provocation test or linked to anesthesia induction or anesthesia withdrawal.

(2) Cough was assessed by an external observer without audio/ video recording.

(3) Papers describing the development of a new cough monitor with no comparison to a reference standard such as video recording.

(4) Invasive methods, which we deemed inappropriate to quantify an uncomplicated cough.

(5) Questionnaires linked to a specific cough etiology that aimed to assess the burden of the pathology [such as lung cancer and chronic obstructive pulmonary disease (COPD), among others] rather than the burden of the cough.

(6) Studies in languages other than French, English, or Dutch.

(7) Studies not conducted in humans. 
Fig. 2. Flow chart. Results of the literature search.

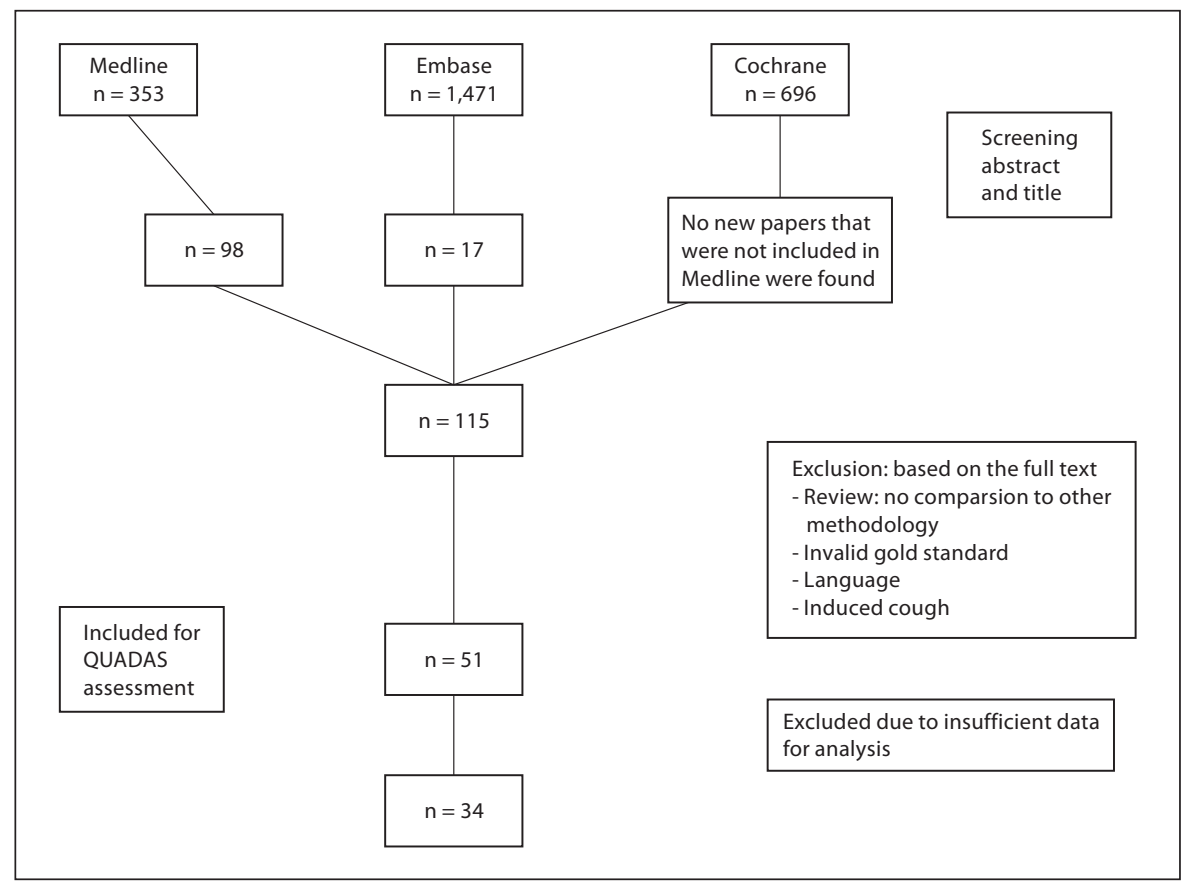

Selection Procedure

Two researchers (S.L. and D.F.) independently selected studies based on the afore mentioned inclusion and exclusion criteria. The relevance of these studies was assessed in 2 successive steps. First, the title and abstract were reviewed and a number of studies excluded. If the researchers were unable to come to a clear conclusion based on the title and abstract, the study was provisionally included. The full texts of the remaining studies were then retrieved and examined against the inclusion/exclusion criteria. Disagreements between the 2 researchers were resolved by consensus. For cases in which no consensus was reached, the third researcher (J.D.) made the final call. Figure 2 depicts the selection procedure.

Evaluation of the Validity of the Included Studies

Those studies that fulfilled the inclusion criteria were then independently evaluated for their methodological quality by 2 researchers (S.L. and D.F.) using the QUADAS grid [11]. No metaanalysis was possible because of the heterogeneity of the inclusion criteria and the outcomes compared in the different studies.

\section{Results}

Thirty-four articles were retained on the basis of the inclusion criteria. Ten of them were validation studies concerning cough frequency monitoring in children and/ or adults [12-21]. Seven studies validating cough-specific quality-of-life scores were included [22-29].

Systematic Review of Cough Assessment Tools
Fifteen studies compared instruments used to measure the perceived severity of the cough (i.e. VDS or VAS) with objective cough frequency measurements or quality-of-life scores. These comparative studies were the only source of evidence we found of attempts to validate these subjective measurements. Twelve of these studies, i.e. 6 in adults [10, 30-34] and 6 in children [19, 35-39], compared subjective measurements with objective cough frequency measurements. Three studies compared subjective methods with a quality-of-life score [28, 40, 41]. Finally, 6 studies compared quality-of-life scores with objective measurements of cough [30, 31, 33, 42-44].

\section{Validation of Tools Used to Measure Cough Frequency or Intensity}

Table 1 shows the cough monitoring validation studies. Four types of technology have been developed to identify coughs and to measure cough frequency. The first type of device is based on audio-recognition alone [7, $13,15]$; the second type of technology is based on audio signals plus electromyography (EMG; by identifying intercostal and/or abdominal muscle contractions, a cough is identified when the audio and EMG signals occur simultaneously) [17, 18]; the third type is based on an accelerometer which measures the vibration at the suprasternal notch alone [16], and the fourth type is a multiparametric device based on plethysmography, electro- 
Table 1. Cough monitoring validation studies

\begin{tabular}{|c|c|c|c|c|c|c|}
\hline $\begin{array}{l}\text { First } \\
\text { author }\end{array}$ & $\begin{array}{l}\text { Patients } \\
\mathrm{n}\end{array}$ & $\begin{array}{l}\text { Patients } \\
\text { included }\end{array}$ & $\begin{array}{l}\text { Recording } \\
\text { conditions }\end{array}$ & $\begin{array}{l}\text { Test description/ } \\
\text { automated detection }\end{array}$ & $\begin{array}{l}\text { Standard } \\
\text { reference }\end{array}$ & Results \\
\hline $\begin{array}{l}\text { Smith, } \\
2006[10]\end{array}$ & 8 & $\begin{array}{l}\text { Subjects with } \\
\text { chronic cough }\end{array}$ & $\begin{array}{l}\text { Overnight in } \\
\text { laboratory }\end{array}$ & $\begin{array}{l}\text { Digital audio recording } \\
\text { Manual counting of period of } \\
\text { interest with sound activity }\end{array}$ & $\begin{array}{l}\text { Manual } \\
\text { count on } \\
\text { video }\end{array}$ & $\begin{array}{l}\text { Mean difference: } 0.3 \text { coughs } / \mathrm{h} \\
\text { (95\% CI }-1.5 \text { to } 0.9 \text { ). } \\
\text { Analysis time: } 8 \mathrm{~h} \text { (video) versus } 2-4 \mathrm{~h} \\
\text { (digital sound recordings) }\end{array}$ \\
\hline $\begin{array}{l}\text { Paul, } \\
2004 \text { [7] }\end{array}$ & 15 & $\begin{array}{l}\text { Subjects with } \\
\text { frequent } \\
\text { coughing }\end{array}$ & $\begin{array}{l}\text { Home, } \\
\text { outpatient, } \\
\text { inpatient for } \\
15-60 \mathrm{~min}\end{array}$ & $\begin{array}{l}\text { Accelerometer } \\
\text { Portable device with no auto- } \\
\text { mated analysis software to assist } \\
\text { manual review of recording }\end{array}$ & Video & $\begin{array}{l}\text { Good interobserver agreement } \\
\text { Correlation coefficient between video } \\
\text { and audio: } \\
\text { investigator 1: } 0.96 \text { ( } 95 \% \text { CI } 0.918-1.00) \\
\text { investigator 2: } 0.97 \text { ( } 95 \% \text { CI } 0.93-1.00)\end{array}$ \\
\hline $\begin{array}{l}\text { Coyle, } \\
2005[21]\end{array}$ & 8 & $\begin{array}{l}\text { Subjects with } \\
\text { COPD and } \\
\text { more than } \\
10 \text { coughs/day }\end{array}$ & $\begin{array}{l}24 \text {-hour } \\
\text { recording in } \\
\text { video room }\end{array}$ & $\begin{array}{l}\text { LifeShirt: combination of } \\
\text { plethysmography, ECG, and EMG } \\
\text { Automated analysis }\end{array}$ & Video & $\begin{array}{l}\text { Sensitivity: } 78.1 \% \text {; specificity: } 99.6 \% \\
\text { Positive predictive value: } 84.6 \% \\
\text { Negative predictive value: } 99.4 \% \\
\text { Kappa: very good }(0.80)\end{array}$ \\
\hline $\begin{array}{l}\text { Barry, } \\
2006[15]\end{array}$ & 10 & $\begin{array}{l}\text { Smokers with } \\
\text { chronic cough }\end{array}$ & $\begin{array}{l}\text { 1-hour } \\
\text { recording at } \\
\text { hospital }\end{array}$ & $\begin{array}{l}\text { Hull Automatic Cough Counter: } \\
\text { digital audio recording } \\
\text { Semiautomated detection, i.e. } \\
\text { cough recognition according to } \\
\text { sound spectrum (probabilistic } \\
\text { neural network) followed by } \\
\text { manual review }\end{array}$ & $\begin{array}{l}\text { Signal visualization } \\
\text { on graphical user } \\
\text { interface and } \\
\text { listening to periods } \\
\text { of interest in real } \\
\text { time by } 2 \\
\text { independent } \\
\text { listeners }\end{array}$ & $\begin{array}{l}\text { Sensitivity: } 80 \% \text { (range } 0.55-1 \text { ) } \\
\text { Specificity: } 96 \% \text { (range } 0.92-0.98 \text { ) }\end{array}$ \\
\hline $\begin{array}{l}\text { Munyard, } \\
1994[18]\end{array}$ & 20 & $\begin{array}{l}4 \text { healthy adults, } \\
1 \text { healthy child, } \\
1 \text { child with } \\
\text { asthma, and } 14 \\
\text { children with } \\
\text { cystic fibrosis }\end{array}$ & $\begin{array}{l}\text { Short duration } \\
(1-8 \mathrm{~h}) \text {, } \\
\text { working adult }\end{array}$ & $\begin{array}{l}\text { EMG }+ \text { microphone }+ \text { ECG } \\
\text { Manual review of graphical } \\
\text { interface }\end{array}$ & Tape recording & $\begin{array}{l}\text { Correlation coefficient: } 0.99 \\
(95 \% \text { CI } 0.96-0.99)\end{array}$ \\
\hline $\begin{array}{l}\text { Matos, } \\
2006[12]\end{array}$ & 19 & $\begin{array}{l}\text { Patients with } \\
\text { cough recruited } \\
\text { from a } \\
\text { specialized } \\
\text { cough } \\
\text { clinic }\end{array}$ & $\begin{array}{l}\text { Usual daily } \\
\text { routine } \\
\text { recording, } \\
\text { mean recording } \\
6 \mathrm{~h} \text {, starting in } \\
\text { the morning }\end{array}$ & $\begin{array}{l}\text { LCM digital audio recording } \\
\text { Semiautomatic analysis: } \\
\text { identifying and then listening } \\
\text { to the recognized signals }\end{array}$ & $\begin{array}{l}\text { Manual counting } \\
\text { of recordings }\end{array}$ & $\begin{array}{l}\text { Mean detection rate: } 71 \% \\
\text { False-positives: } 13 / \mathrm{h}\end{array}$ \\
\hline $\begin{array}{l}\text { Birring, } \\
2008[13]\end{array}$ & 23 & $\begin{array}{l}15 \text { adults } \\
\text { suffering from } \\
\text { chronic cough } \\
\text { and } \\
8 \text { volunteers }\end{array}$ & $\begin{array}{l}\text { 6-hour } \\
\text { recording }\end{array}$ & $\begin{array}{l}\text { LCM } \\
\text { Semiautomated analysis, operator } \\
\text { must classify a small fraction of } \\
\text { the sound detected }\end{array}$ & $\begin{array}{l}\text { Manual counting } \\
\text { of audio recordings } \\
\text { on LCM }\end{array}$ & $\begin{array}{l}\text { Mean difference: }-4 \text { coughs/h/patient } \\
\text { (95\% CI }-6 \text { to } 13 \text { coughs/h; } \mathrm{p}=0.4 \text { ) } \\
\text { Sensitivity: } 91 \% \text {; specificity: } 99 \%\end{array}$ \\
\hline $\begin{array}{l}\text { Corrigan, } \\
2003[20]\end{array}$ & 28 & $\begin{array}{l}\text { Healthy } \\
\text { newborns and } \\
\text { children under } \\
1 \text { year of age } \\
\text { admitted for } \\
\text { cough (main } \\
\text { symptom) }\end{array}$ & $\begin{array}{l}\text { Ambulatory } \\
\text { or hospitalized } \\
\text { recumbent } \\
\text { babies; crying } \\
\text { was excluded } \\
\text { from the } \\
\text { analysis }\end{array}$ & $\begin{array}{l}\text { LR100 = EMG + audio signal } \\
\text { Automated tagging followed by } \\
\text { manual review }\end{array}$ & $\begin{array}{l}\text { Audio counting } \\
\text { of periods with } \\
\text { visualized activity }\end{array}$ & $\begin{array}{l}\text { Mean sensitivity: } 81 \% \\
\text { PPV: } 0.81 \\
\text { Mean difference: } 0.36 \text { coughs } / \mathrm{h} \\
\text { ( } 95 \% \text { CI }-0.53 \text { to } 0.63 \text { coughs } / \mathrm{h} \text { ) }\end{array}$ \\
\hline $\begin{array}{l}\text { Chang, } \\
1997[17]\end{array}$ & 18 & $\begin{array}{l}\text { Healthy } \\
\text { children and } \\
\text { children } \\
\text { suffering from } \\
\text { nonspecific } \\
\text { recurrent cough }\end{array}$ & $\begin{array}{l}\text { Overnight, } \\
8-10 \mathrm{~h}\end{array}$ & $\begin{array}{l}\text { EMG and audio signal; } \\
\text { visual reading of recording } \\
\text { No automated analysis }\end{array}$ & Tape recording & $\begin{array}{l}\text { Mean difference: }-0.3 \text { coughs } / \mathrm{h} \\
(-0.7 \text { to } 0.2) \\
\text { Limits of agreement: }-2.2 \text { to } 1.7 \text { coughs } / \mathrm{h}\end{array}$ \\
\hline $\begin{array}{l}\text { Hamutcu, } \\
2002[19]\end{array}$ & 14 & $\begin{array}{l}\text { Patients } \\
\text { hospitalized for } \\
\text { exacerbation of } \\
\text { cystic fibrosis }\end{array}$ & $\begin{array}{l}\text { Count during } \\
\text { chest } \\
\text { physiotherapy }\end{array}$ & $\begin{array}{l}\text { Modified LR100: cough defined } \\
\text { as a rapid phasic burst in audio } \\
\text { and EMG signals } \\
\text { Semiautomated analysis }\end{array}$ & $\begin{array}{l}\text { Audio count during } \\
\text { chest physiotherapy }\end{array}$ & $\begin{array}{l}\mathrm{r}^{2}=0.96(95 \% \text { CI } 0.89-0.98) \\
\text { Difference: } 0.5 \text { episodes/session }\end{array}$ \\
\hline
\end{tabular}


cardiography, and an accelerometer (LifeShirt; VivoMetrics) [21]. All of these can potentially be used in an ambulatory setting. Only 1, the LR102 (Logan Sinclair) (a type 2 device), has been validated for use in children [19]. The following 3 devices provide partially or completely automated analyses: the LifeShirt, the Leicester Cough Monitor (LCM), and the LR102. The automated analysis of the LifeShirt has been validated under controlled conditions in COPD patients, although its sensitivity (79\%) could be improved. The LCM provides a partially automated analysis. The LR102 provides a completely automated analysis of cough episodes, but it has only been validated in its manual counting mode and measurements of numbers of single cough or cough seconds require manual reading of the indentified cough epoch.

Measurement units are the explosive sound each time the patient coughs $[13,15,21,32]$ or the coughing episode [18] occurs, and the events are defined as separate from one another by a free interval of a determined duration. Cough frequency can also be expressed in units of time spent coughing (e.g. the number of seconds per hour, including a minimum of 1 explosive coughing sound) [16].

The intensity of the signal can potentially be captured in several devices and 1 group of authors mentions they did so [16]. However, they did not report on this. Furthermore, none of the monitors provide an automated analyses of such signals.

According to the QUADAS tool, the quality of the studies varied (fig. 3). The conditions under which the instruments were validated ranged from highly controlled conditions, such as a video room, to actual ambulatory conditions. Some of the cough frequency meters were only validated during the night. The conditions of validation are important because the likelihood of environmental noise and the degree of patient mobility are likely to affect the accuracy of such devices.

\section{Validation of Quality-of-Life Scores}

The validation of quality-of-life scores is shown in table 2 . Three scales have been validated but only for subjects with chronic cough. The Leicester Cough Questionnaire (LCQ) was developed and validated in English [25]. A Dutch translation has also been validated [22]. The Cough Quality of Life Questionnaire (CQLQ) was developed and validated in English [26, 28, 29]. One scale has been validated in the parents of children suffering from chronic cough in Australia [27], and 1 scale was developed and validated in Italian $[23,24]$.

All 4 of these studies used internal consistency as an indicator of reliability. The Italian scale also examined

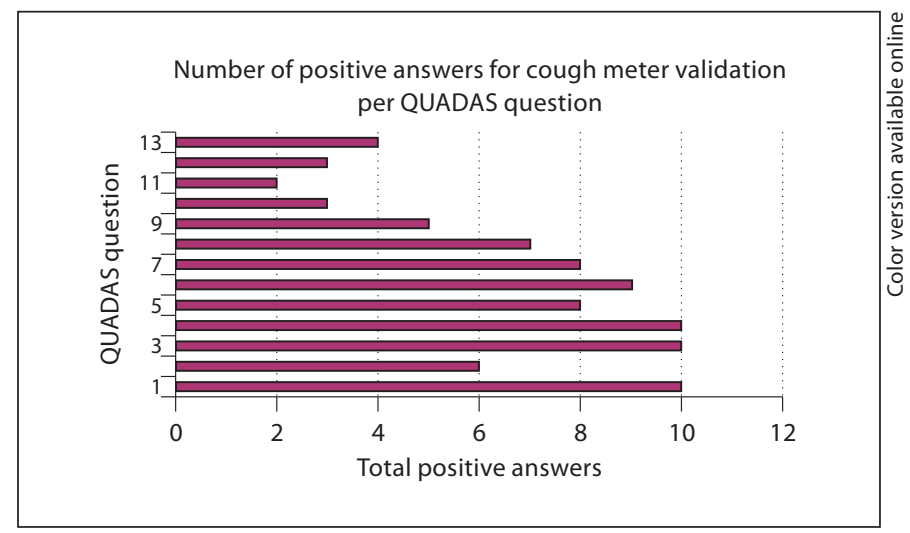

Fig. 3. Global quality of the included studies on cough meter validation. For each study, 13 questions from the QUADAS tools were assessed and 1 point was given if the study fulfilled this criteria. The figure represents the number of studies including each QUADAS criteria.

the scale's reproducibility and responsiveness to change. Except for the CQLQ, the scores for these instruments were compared with the scores obtained with a generic quality-of-life tool.

\section{Comparisons of VDS and/or VAS and Other \\ Measurements}

The correlations between VDS or VAS and objective cough measurements or quality-of-life scores are inconsistent. This is true when they are used in both adults and children. The correlations vary not only according to the precise instrument, but even for the same instrument according to the time the measurement is made. For example, the correlation between VDS and/or VAS and a cough frequency measurement ranged from 0.07 [95\% confidence interval (CI) -0.33 to 0.448 ] to 0.81 ( $95 \%$ CI -0.614 to 0.912 ), depending on the setting of the study and the period evaluated (day or night analysis) [10, 30-34]. The same lack of a consistent correlation was found in children $[19,35-39]$ and for comparisons with quality-of-life tools $[28,40,41]$. Various descriptive scores and quality-of-life tools were used in different studies. The diseases that were investigated were asthma, cystic fibrosis, COPD, seasonal rhinitis, and primitive ciliary dyskinesia, all of which are associated with chronic or recurrent coughing. We found no studies that examined the perceived severity of an acute cough. Tables 3-5 present comparisons between VDS and/or VAS and other measurements.

The quality of the studies in this section was rather good and homogeneous (fig. 4). 
Table 2. Validation of quality-of-life scores

\begin{tabular}{|c|c|c|c|c|}
\hline First author & Patients, $\mathrm{n}$ & Population included & Scale & Creation of scale; internal validity \\
\hline $\begin{array}{l}\text { Birring, } \\
2003[13]\end{array}$ & $\begin{array}{l}104 \text { for generation } \\
\text { items } \\
56 \text { for comparison to } \\
\text { other scales } \\
24 \text { for reproducibility } \\
9 \text { for responsiveness }\end{array}$ & $\begin{array}{l}\text { Adults (mean age } 57 \text { years) } \\
\text { with unexplained aspecific } \\
\text { chronic cough }\end{array}$ & LCQ & $\begin{array}{l}\text { (1) Generation of items following } \\
\text { interviews of patients and professionals } \\
\text { (2) Reduction of items } \\
\text { (3) Allocation into domains } \\
\text { Cronbach's } \alpha \text { : } \\
\text { total } 0.92 \\
\text { physical } 0.79 \\
\text { psychological } 0.89 \\
\text { social } 0.85\end{array}$ \\
\hline $\begin{array}{l}\text { French, } \\
2002[26]\end{array}$ & 215 & $\begin{array}{l}\text { Adults with a chronic cough of } \\
\text { more than } 8 \text { weeks in duration } \\
\text { Adults suffering from acute } \\
\text { cough Smokers with cough but } \\
\text { no complaints }\end{array}$ & CQLQ & $\begin{array}{l}\text { Factor analysis } \\
\text { Cronbach's } \alpha \text { : } \\
\text { total } 0.92 \\
\text { physical } 0.85 \\
\text { psychosocial } 0.83 \\
\text { functional } 0.86 \\
\text { emotional } 0.7 \\
\text { extreme physical } 0.7 \\
\text { personal safety } 0.63\end{array}$ \\
\hline $\begin{array}{l}\text { Huisman, } \\
2007 \text { [22] }\end{array}$ & 152 & $\begin{array}{l}\text { Patients with chronic cough } \\
\text { (mean age } 59 \text { years) } \\
\text { hospitalized - third line }\end{array}$ & Translated LCQ & Cronbach's $\alpha: 0.77-0.91$ \\
\hline $\begin{array}{l}\text { Baiardini, } \\
2005[23]\end{array}$ & $\begin{array}{l}170 \text { for the item } \\
\text { reduction question } \\
95 \text { for validation }\end{array}$ & $\begin{array}{l}\text { Patients with chronic cough } \\
\text { (mean age } 57 \text { years) }\end{array}$ & Italian scale & $\begin{array}{l}\text { Literature review, experts' and pulmonologists' } \\
\text { unstructured interviews with patients } \\
\text { Item reduction by patients, degree of importance, } \\
\text { internal consistency (Cronbach's } \alpha \text { between } 65 \text { and } 86 \text { ) }\end{array}$ \\
\hline $\begin{array}{l}\text { Braido, } \\
2006[24]\end{array}$ & 95 & Adults with chronic cough & $\begin{array}{l}\text { Italian score of } \\
\text { quality of life }\end{array}$ & \\
\hline $\begin{array}{l}\text { Kalpaklioglu, } \\
2005[28]\end{array}$ & 40 & $\begin{array}{l}\text { Patients aged } 10-69 \text { years } \\
\text { referred third line for chronic } \\
\text { cough }\end{array}$ & CQLQ and LCQ & \\
\hline
\end{tabular}

\begin{tabular}{|c|c|c|c|c|}
\hline $\begin{array}{l}\text { Newcombe, } \\
2008 \text { [27] }\end{array}$ & 170 & $\begin{array}{l}\text { Children referred for chronic } \\
\text { cough }\end{array}$ & $\begin{array}{l}\text { Burden of cough } \\
\text { questionnaire }\end{array}$ & $\begin{array}{l}\text { Items generated from informal discussions with } \\
\text { patients following the Juniper asthma questionnaire } \\
\text { Reduction according to } 2 \text { methods: } \\
\text { Clinical impact: } 27 \text { items } \\
\text { internal consistency: } 0.94 \\
\text { interitem correlation: } r s=0.12-0.87 \\
\text { Psychometric method: } \\
\text { full scale Cronbach's } \alpha \text { : } 0.92 \\
\text { internal consistency: moderate to strong } \\
\text { interitem correlation: } r s=0.39-0.57\end{array}$ \\
\hline $\begin{array}{l}\text { Polley, } \\
2008 \text { [29] }\end{array}$ & 147 & $\begin{array}{l}\text { Patients referred for chronic } \\
\text { cough } \\
\text { Stable patients suffering from } \\
\text { asthma } \\
\text { COPD patients } \\
\text { Patients with bronchiectasis }\end{array}$ & European QoL & $\begin{array}{l}\text { LCQ } \\
\text { CQLQ }\end{array}$ \\
\hline
\end{tabular}




\begin{tabular}{|c|c|c|}
\hline Reproducibility & Comparison & Responsiveness \\
\hline Intraclass correlation (total scale): 0.96 & $\begin{array}{l}\text { Spearman's correlation of LCQ with VAS: rs }=0.72 \\
\text { St George's Respiratory Questionnaire: rs }=0.54 \\
\text { Short-form 36-item (SF36) health status questionnaire: } \\
\text { rs }=0.46\end{array}$ & $\begin{array}{l}\text { After treatment, effect size: } \\
\text { physical } 1 \\
\text { psychological } 1.75 \\
\text { social } 0.84 \\
\text { LCQ total } 1.68\end{array}$ \\
\hline $\begin{array}{l}\text { Test-retest: } \\
\text { paired } t \text { test }=\text { difference } \\
\text { not significant } \\
\mathrm{r}(\text { total scale })=0.89\end{array}$ & $\begin{array}{l}\text { Not with other scales but comparison between groups } \\
\text { of patients (complaining and noncomplaining coughing patients) } \\
\text { ANOVA followed by Tukey HSD: significant difference between } \\
\text { groups of patients }\end{array}$ & $\begin{array}{l}\text { Measured in chronic cough: } \\
\mathrm{p}<0.01 \text { (statistically significant) } \\
\text { for total scale and subscales }\end{array}$ \\
\hline Intraclass correlation: $0.86-0.93$ & $\begin{array}{l}\text { Comparison scale with: } \\
\text { SF36 }(\mathrm{r}=0.41) \\
\text { Borg cough scale }(\mathrm{r}=-0.41) \\
\text { HADS (hospital anxiety and depression scale) }(\mathrm{r}=-0.46)\end{array}$ & Improvement score: 5.28 (4.41-6.15) \\
\hline \multirow[t]{5}{*}{$\begin{array}{l}\text { Readministered after } 1 \text { week to } \\
22 \text { untreated stable patients: } \\
\text { good reliability (range } 0.67-0.88 \text { ) }\end{array}$} & SF36: low correlation for most items & $\begin{array}{l}15 \text { days, posttreatment group of } 25 \\
\text { asthmatic patients: statistically significant } \\
\text { difference for } 16 \text { out of } 21 \text { items }\end{array}$ \\
\hline & $\begin{array}{l}\text { Significant correlation between SF } 36 \text { and CCIQ for daily life } \\
\text { impact, but not for other domains }\end{array}$ & \\
\hline & $\begin{array}{l}\text { Significant correlation between specific and generic QoL except } \\
\text { between CQLQ and mental for SF36 } \\
\text { Correlation between component HADS and LCQ: } \\
\mathrm{r}=-0.48 \text { for anxiety }(95 \% \text { CI }-0.66 \text { to }-0.24) \\
\mathrm{r}=-0.69 \text { for depression }(95 \% \text { CI }-0.8 \text { to }-0.52) \\
\text { Correlation between CQLQ and LCQ: } \\
\text { Pretreatment: } \mathrm{r}=-0.42 .(95 \% \text { CI }-0.61 \text { to } 0.17) \\
\text { Posttreatment: } \mathrm{r}=-0.60(95 \% \text { CI }-0.74 \text { to }-0.39) \\
\text { Correlation between CQLQ and baseline anxiety: } \\
\mathrm{r}=0.34(95 \% \text { CI } 0.08-0.55)\end{array}$ & Effect size 1 or greater \\
\hline & $\begin{array}{l}\text { Comparison with Pediatric Quality of Life Inventory, } \\
\text { version } 4.0 \text { (PedsQL4.0); } 12 \text {-item Short Form Health } \\
\text { Survey, version } 2 \text { (SF-12v2) } \\
\text { Cronbach (between } 0.56 \text { and } 0.91 \text { ) } \\
\text { Spearman's correlation: } 0.01 \text { and }-0.69\end{array}$ & $\begin{array}{l}\text { Response following treatment was } \\
\text { significant for the } 2 \text { scales }\end{array}$ \\
\hline & $\begin{array}{l}\text { Different associations between LCQ and CQLQ according to } \\
\text { pathology: } \\
\text { Chronic cough: } \mathrm{r}=-0.56(95 \% \text { CI }-0.647 \text { to } 0.458) \\
\text { COPD: } \mathrm{r}=0.49(95 \% \text { CI } 0.379-0.587) \\
\text { Asthma: } \mathrm{r}=-0.94(95 \% \text { CI }-0.954 \text { to }-0.922) \\
\text { Bronchiectasis: } \mathrm{r}=-0.88 \text { ( } 95 \% \text { CI }-0.908 \text { to } 0.845) \\
\text { Euro QoL and LCQ: } \mathrm{r}=0.48(95 \% \text { CI } 0.367-0.579) \\
\text { Euro Qol and CQLQ: } \mathrm{r}=-0.53 \text { (95\% CI }-0.622 \text { to } 0.424)\end{array}$ & \\
\hline
\end{tabular}


Table 3. Comparison of descriptive scores of cough impact or visual analogue scales versus validated cough frequency counting in adults

\begin{tabular}{llllll}
\hline $\begin{array}{l}\text { First } \\
\text { author }\end{array}$ & $\begin{array}{l}\text { Patients } \\
\mathrm{n}\end{array}$ & Mean cough frequency & Population included & Validation conditions & Test description \\
\hline $\begin{array}{l}\text { Smith, } \\
2006[30]\end{array}$ & 19 & $\begin{array}{l}\text { Median: } 8.27 \\
\text { (IQR 5.94-11.67) }\end{array}$ & $\begin{array}{l}\text { COPD patients with } \\
\text { cough score greater } \\
\text { than 2 }\end{array}$ & $\begin{array}{l}\text { Home: day }(10 \text { h) and } \\
\text { night }(10 \text { h) }\end{array}$ & $\begin{array}{l}\text { EVA and } \\
\text { descriptive scores }\end{array}$
\end{tabular}

\begin{tabular}{|c|c|c|c|c|c|}
\hline $\begin{array}{l}\text { Declamer, } \\
2007 \text { [31] }\end{array}$ & 62 & $\begin{array}{l}\text { Median (day): } 15.59 \text { coughs/h } \\
\text { (IQR 1.06-46) } \\
\text { Median (night): } 2.94 \text { coughs/h } \\
\text { (IQR 0-26) }\end{array}$ & $\begin{array}{l}\text { Patients with chronic } \\
\text { cough more than } \\
8 \text { weeks in duration }\end{array}$ & $\begin{array}{l}\text { Normal routine: daily } \\
\text { ambulatory analysis } \\
\text { (night and day) }\end{array}$ & EVA and score \\
\hline
\end{tabular}

\begin{tabular}{lllll}
\hline $\begin{array}{l}\text { Smith, } \\
2006[30]\end{array}$ & $\begin{array}{l}\text { Median on admission (coughs/h): } \\
\text { day: } 21.2(\text { IQR 14-34.9) }\end{array}$ & $\begin{array}{l}\text { Adult patients } \\
\text { hospitalized for } \\
\text { night: } 4.8 \text { (IQR 1-6.8) }\end{array}$ & $\begin{array}{l}\text { Sxacerbation of } \\
\text { cystic fibrosis }\end{array}$ & $\begin{array}{l}\text { at 10:00 p.m. for a duration } 10 \mathrm{~h} \\
\text { of }\end{array}$ \\
& &
\end{tabular}

\begin{tabular}{|c|c|c|c|c|c|}
\hline $\begin{array}{l}\text { Smith, } \\
2006[30]\end{array}$ & 26 & $\begin{array}{l}\text { Median: } 7.51 \text { coughs/h } \\
\text { (range } 2.67-23.11 \text { ) }\end{array}$ & $\begin{array}{l}\text { Patients with COPD } \\
\text { and chronic cough }\end{array}$ & $\begin{array}{l}\text { Ambulatory: night }(10 \mathrm{~h}) \\
\text { and day }(10 \mathrm{~h}) \\
\text { Patient walking at home }\end{array}$ & VAS and score \\
\hline $\begin{array}{l}\text { Krahnke, } \\
2004[34]\end{array}$ & 28 & $\begin{array}{l}\text { Mean } \pm \text { SD: } 197 \pm 157 \text { bouts } \\
\text { per baseline session }(24 \mathrm{~h})\end{array}$ & $\begin{array}{l}\text { Patients older than } \\
12 \text { years with seasonal } \\
\text { allergic rhinitis }\end{array}$ & $\begin{array}{l}\text { Ambulatory: } 24 \text {-hour } \\
\text { recording but patients must } \\
\text { stay within a certain range } \\
\text { of monitoring }\end{array}$ & $\begin{array}{l}\text { Diary card } \\
\text { semi-quantitative } \\
\text { scale }\end{array}$ \\
\hline $\begin{array}{l}\text { Marsden, } \\
2008[44]\end{array}$ & 56 & Median: 2.6 cough seconds/h & 56 asthma patients & $\begin{array}{l}\text { Ambulatory: } \\
\text { recording for } 24 \mathrm{~h}\end{array}$ & $\begin{array}{l}\text { Numeric cough } \\
\text { scores } \\
\text { VAS }\end{array}$ \\
\hline
\end{tabular}

\section{Comparison of Cough Frequency and Quality-of-Life Scores}

The LCQ correlated well with objective cough frequency measurements in 4 studies ( $\mathrm{r}$ values ranged between -0.53 and -0.60$)[31,33,43,44]$. The CQLQ correlated moderately well with objective measures in 2 studies $(\mathrm{r}=0.30)$ [30]. Another study reported a good correlation but did not provide an exact value for the correlation coefficient [42]. A comparison between cough frequency and quality-of-life scores is displayed in table 6 .

\section{Discussion}

This systematic review has identified several cough frequency meters that are accurate, require little time for analysis, and are suitable for use in an ambulatory setting. Automated analyses (totally automated or quasi-totally automated) are available for 3 devices: the LR102, the LifeShirt, and the LCM. However, the automated analysis of the LR102 has yet to be validated. Access to these devices is currently limited, and none of them measures 


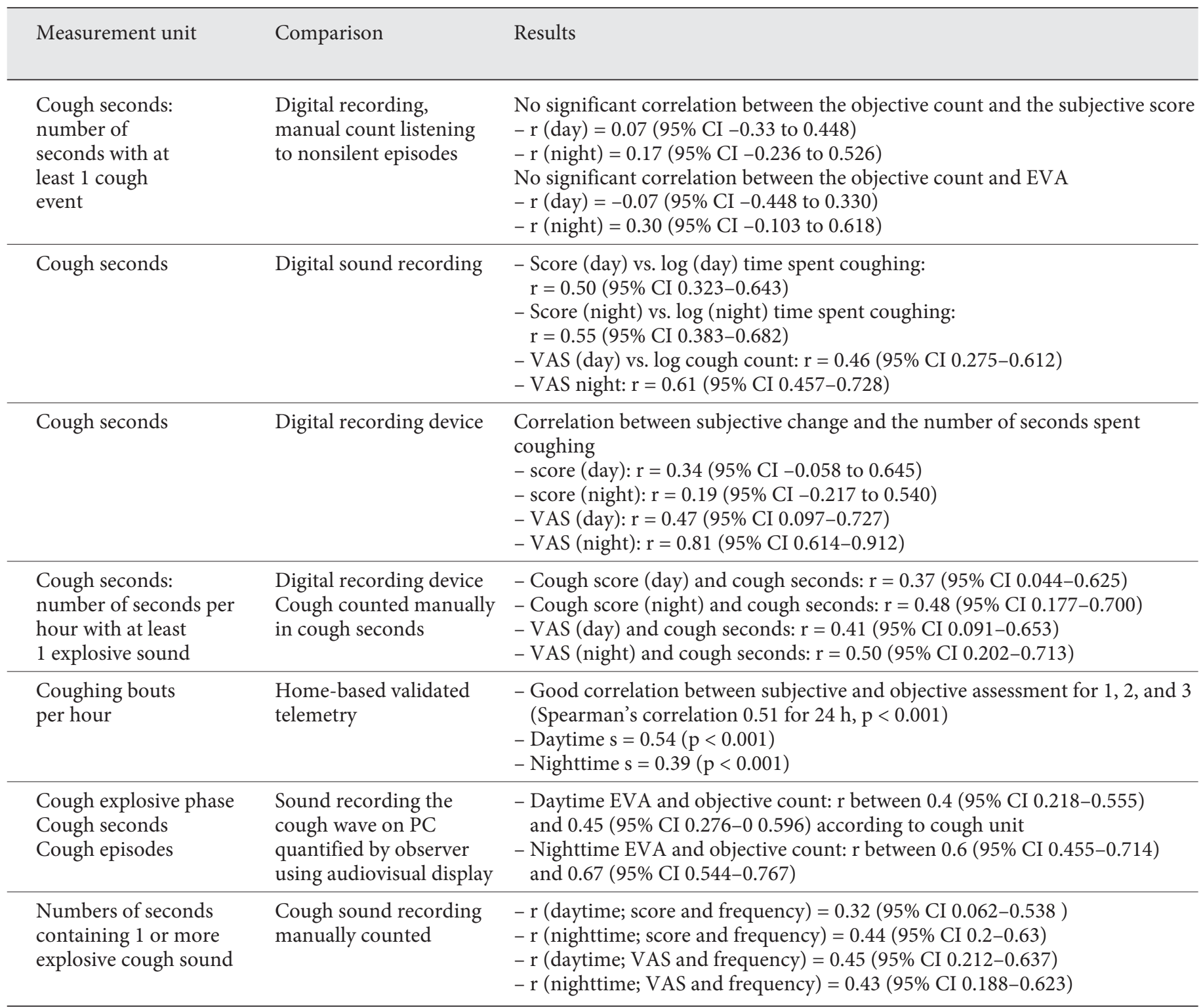

cough intensity in an automated mode. The cough's intensity, which can be measured by several monitors, is related to the intensities of the measured signal (loudness, intensity muscular contraction, and intensity of thoracic amplitude). It remains to be shown how the intensity of these signals is nearest to the intensity of the expulsive efforts. It also remains to be proven whether cough intensity correlates better than cough frequency with the impact of cough on quality of life.
There are several limitations to the studies examined. The numbers of participants were limited. The recording conditions were not always similar to real-life situations. Validations under laboratory conditions could overestimate the specificity of the monitor and reduce the number of false-positive counts because of the interference caused by patient movements and background noise. Furthermore, comprehensive validation of the automatic analyses of the devices requires that they be tested across wide ranges of cough frequencies, cough loudness, and 
Table 4. Comparison of score or visual analogue scale to an objective cough count in children

\begin{tabular}{|c|c|c|c|c|c|c|}
\hline $\begin{array}{l}\text { Chang, } \\
1998 \text { [36] }\end{array}$ & 84 & $\begin{array}{l}\text { Median daytime cough } \\
\text { frequency in coughing } \\
\text { patients: } 61 \text { coughs } / 24 \mathrm{~h} \\
\text { (IQR } 159) \text {; in noncoughers: } \\
10 \text { coughs/ } 24 \text { h (IQR }-15 \text { ) } \\
\text { Nighttime cough } \\
\text { frequency in coughing } \\
\text { patients: } 2.5 \text { (IQR } 20 \text { ); } \\
\text { in noncoughers: } \\
0 \text { (IQR 2.7) }\end{array}$ & $\begin{array}{l}\text { Children aged } 6-17 \\
\text { years with recurrent } \\
\text { non-specific cough in } \\
\text { the respiratory } \\
\text { outpatient department }\end{array}$ & $\begin{array}{l}24 \mathrm{~h}, \text { normal } \\
\text { activity }\end{array}$ & EVA $(1-10)$ & Undefined \\
\hline $\begin{array}{l}\text { Hamutcu, } \\
2002[19]\end{array}$ & 10 & $\begin{array}{l}\text { Mean } \pm \text { SD on } \\
\text { admission: } 18.2 \pm 8.4 \\
\text { episodes/h during the day } \\
\text { and } 5.8 \pm 2.9 \text { at night }\end{array}$ & $\begin{array}{l}\text { Patients hospitalized } \\
\text { for exacerbation of } \\
\text { cystic fibrosis }\end{array}$ & $\begin{array}{l}17 \mathrm{~h} \text {, recording } \\
\text { in hospital }\end{array}$ & $\begin{array}{l}\text { VAS, descriptive } \\
\text { score for daytime } \\
\text { and nighttime }\end{array}$ & $\begin{array}{l}\text { Cough episodes with } \\
\text { a minimum interval } \\
\text { of } 2 \mathrm{~s} \text { free between } \\
\text { them }\end{array}$ \\
\hline $\begin{array}{l}\text { Chang, } \\
2003 \text { [37] }\end{array}$ & 40 & $\begin{array}{l}\text { Median: } \\
\text { Day 1: } 75 \\
\text { coughs/h }(9-719) \\
\text { Day 7: } 44 \\
\text { coughs/h }(0-500)\end{array}$ & $\begin{array}{l}\text { Children aged } 6-17 \\
\text { years with recurrent } \\
\text { cough }\end{array}$ & $24 \mathrm{~h}$ & $\begin{array}{l}\text { VAS, descriptive } \\
\text { score }\end{array}$ & \\
\hline
\end{tabular}

cough patterns, and during both day- and nighttime. Some of these devices (LCM) still produce false-positive results when subjects clear their throats or when nearby individuals cough. Finally, the review process was limited to validation studies published in English, French, or Dutch. Other validation studies may have been published in other languages. Papers reporting the development of cough monitors were excluded.
Quality-of-life scales have been validated in adults with chronic cough and in the close relatives of children suffering from chronic cough and can thus be usefully applied in this context [25-27]. Further studies could evaluate the impact of cough under acute conditions.

This literature review did not identify any validation studies of VDS or VAS. However, these are very widely used as outcome measures in intervention studies and are promoted in guidelines for cough assessment [45]. The cor- 


\begin{tabular}{ll}
\hline $\begin{array}{l}\text { Description of cough } \\
\text { frequency measure }\end{array}$ & Results \\
\hline
\end{tabular}

Microphone with vocal activator and manual control
Correlation between log of nocturnal cough frequency and parental nocturnal score: $\mathrm{r}=0.588$ (95\% CI 0.214-0.812) during CRS week but no significant correlation with placebo

EMG and microphone (22)

Daytime cough:

- subjects: $100 \%$

- controls: $\mathrm{k}=0.61$ for child-completed chart; $\mathrm{k}=0.44$ for parent-completed chart

Nighttime cough:

- subjects: $\mathrm{k}=0.11$ (parents); $\mathrm{k}=0.22$ (child)

- controls: $\mathrm{k}=0.16$ (parents); $\mathrm{k}=0.24$ (child)

- correlation between cough frequency count and VAS completed by parents:

rs $=0.6(95 \%$ CI $0.42-0.73)$

- correlation between cough frequency count and VCD: rs $=0.65$ (95\% CI 0.5-0.77)

LR100

No significant correlation between VAS or score and objective count (data not given)

EMG and microphone (22)

Day 1: $\log$ cough frequency per $24 \mathrm{~h}$ and $\log$ cough score

- child: $r=0.32(95 \%$ CI $0.01-0.57)$

- parent: $r=0.32(95 \%$ CI 0.01-0.58)

Day 7:

- child: $\mathrm{r}=0.44$ (95\% CI 0.13-0.67)

- parent: $\mathrm{r}=0.42(95 \%$ CI $0.11-0.65)$

LR102

No significant correlation between daytime cough $(\mathrm{p}=0.63)$ and nighttime cough $(\mathrm{p}=0.717)$ and the recorded frequency (data not given)

LR100, automatic analysis with manual revision
- r (daytime; score and frequency) $=0.93$ (95\% CI 0.872-0.962)

$-r$ (nighttime; score and frequency) $=0.71 .(95 \%$ CI $0.515-0.835)$

- VAS and frequency: $r=0.906$ (95\% CI 0.830-0.949) relations of these scores and scales with quality-of-life scores or with measures of cough frequency vary considerably. VDS are often based on a mixture of items related to the perception of cough frequency and the perception of its impact on the patient's life. Therefore, it is very difficult to interpret precisely what the scores represent. Patients' perceptions of the importance of their cough when measured by VAS or VDS may be influenced by elements other than cough frequency or its repercussions on the patient's qual- ity of life. It is likely that factors such as disease, duration of illness, patient mood, cough intensity, and global context play roles in these perceptions. Despite having good face validity, these scores and scales cannot be regarded as validated tools indicative of cough frequency or the repercussions of the cough on the patient's quality of life.

The correlation between the total quality-of-life score measured with the LCQ and the cough frequency count is quite good. This suggests that cough frequency has an 
Table 5. Comparison between the validated quality of life score and the descriptive score or visual scale

\begin{tabular}{|c|c|c|c|c|c|c|}
\hline $\begin{array}{l}\text { First } \\
\text { author }\end{array}$ & $\begin{array}{l}\text { Patients } \\
\mathrm{n}\end{array}$ & $\begin{array}{l}\text { Population } \\
\text { included }\end{array}$ & $\begin{array}{l}\text { Validation } \\
\text { conditions }\end{array}$ & $\begin{array}{l}\text { Descriptive } \\
\text { score or EVA }\end{array}$ & $\begin{array}{l}\text { Scale used for } \\
\text { quality of life }\end{array}$ & Results \\
\hline $\begin{array}{l}\text { Torrego, } \\
2006[41]\end{array}$ & 42 & $\begin{array}{l}\text { Stable patients } \\
\text { with bronchectasis } \\
\text { vs. healthy patients }\end{array}$ & Unspecified & $\begin{array}{l}\text { Night- and } \\
\text { daytime score: } \\
0-5\end{array}$ & LCQ & $\begin{array}{l}\text { Strong negative relationship between score and } \\
\text { LCQ } \\
r=-0.9(95 \% \text { CI }-0.940 \text { to } 0.836)\end{array}$ \\
\hline $\begin{array}{l}\text { Kalpaklioglu, } \\
2005[28]\end{array}$ & 40 & $\begin{array}{l}\text { Third-line referred } \\
\text { patients with } \\
\text { chronic cough }\end{array}$ & Ambulatory & Score: $1-5$ & LCQ-CQLQ & $\begin{array}{l}\text { Significant correlation before treatment } \mathrm{b}=0.415 \\
\text { (score-CQLQ), } \mathrm{B}=-0.272 \text { (LCQ); } \mathrm{p}=0.008 \\
\text { No significant correlation after treatment } \\
\text { Note: neither symptoms nor cough duration } \\
\text { appeared to play a role in patients' pretreatment } \\
\text { anxiety or depression }\end{array}$ \\
\hline $\begin{array}{l}\text { Marchant, } \\
2008[40]\end{array}$ & 190 & $\begin{array}{l}\text { Newly referred } \\
\text { children suffering } \\
\text { from chronic cough }\end{array}$ & Ambulatory & Score: $1-5$ & $\begin{array}{l}\text { Burden cough score: } \\
\text { Clinical impact: } 27 \text { items } \\
\text { Psychometric: } 26 \text { items }\end{array}$ & $\begin{array}{l}\mathrm{rs}=-0.17 ; \mathrm{p}=0.042 \text { for clinical impact scale } \\
\mathrm{rs}=-0.23 ; \mathrm{p}=0.005 \text { for psychometric scale }\end{array}$ \\
\hline
\end{tabular}

Table 6. Comparison of quality-of-life scores with cough frequency

\begin{tabular}{|c|c|c|c|c|c|c|c|}
\hline $\begin{array}{l}\text { First } \\
\text { author }\end{array}$ & $\begin{array}{l}\text { Patients } \\
\mathrm{n}\end{array}$ & $\begin{array}{l}\text { Cough } \\
\text { frequency }\end{array}$ & Inclusion & $\begin{array}{l}\text { Validation } \\
\text { conditions }\end{array}$ & Count & Scale & Results \\
\hline $\begin{array}{l}\text { Jeyakumar, } \\
2006[42]\end{array}$ & 28 & Not specified & $\begin{array}{l}\text { Patients with } \\
\text { chronic cough } \\
\text { for more than } \\
6 \text { months }\end{array}$ & Ambulatory & $\begin{array}{l}\text { Estimated reduction } \\
\text { in cough frequency } \\
(100 \%, 75 \% \ldots)\end{array}$ & CQLQ & Strong correlation (data not given) \\
\hline $\begin{array}{l}\text { Birring, } \\
2006[13]\end{array}$ & 29 & $\begin{array}{l}\text { Mean: } 43(8) \\
\text { coughs/h for } \\
\text { chronic cough } \\
\text { and } 2(1) \text { coughs/h } \\
\text { in healthy controls }\end{array}$ & $\begin{array}{l}20 \text { patients } \\
\text { suffering from } \\
\text { chronic cough } \\
\text { and } 9 \text { healthy } \\
\text { subjects }\end{array}$ & Ambulatory & $\begin{array}{l}\text { Digital ambulatory } \\
\text { cough monitoring }\end{array}$ & LCQ & $\begin{array}{l}\text { Correlation between cough } \\
\text { frequency and } \\
\text { LCQ: total } r=-0.6 \\
(95 \% \text { CI }-0.769 \text { to } 0.354)\end{array}$ \\
\hline $\begin{array}{l}\text { Smith, } \\
2006[14]\end{array}$ & 26 & $\begin{array}{l}\text { Median: } 7.51 \\
\text { coughs/h (range } \\
2.67-23.11)\end{array}$ & $\begin{array}{l}\text { COPD and } \\
\text { chronic cough } \\
\text { patients }\end{array}$ & $\begin{array}{l}\text { Ambulatory } \\
\text { (night and day) }\end{array}$ & $\begin{array}{l}\text { Digital recording } \\
\text { device: cough } \\
\text { counted manually } \\
\text { in cough seconds }\end{array}$ & $\begin{array}{l}\text { EVA } \\
\text { and } \\
\text { CQLQ }\end{array}$ & $\begin{array}{l}\text { Total } r=0.36(95 \% \text { CI } 0.33-0.617) \\
\text { Nighttime } r=0.05 \\
(95 \% \text { CI }-0.286 \text { to } 0.375) \\
\text { Daytime } r=0.29 \\
(95 \% \text { CI }-0.045 \text { to } 0.567)\end{array}$ \\
\hline $\begin{array}{l}\text { Declamer, } \\
2007[31]\end{array}$ & 62 & $\begin{array}{l}\text { Median (day): } \\
15.59 \text { (range } 1.06-46) \\
\text { Median (night): } \\
2.94 \text { (range 0-26) }\end{array}$ & $\begin{array}{l}\text { Patients with } \\
\text { chronic cough } \\
\text { for more than } 8 \\
\text { weeks (median }= \\
5.5 \text { years) }\end{array}$ & $\begin{array}{l}\text { Normal routine } \\
\text { ambulatory } \\
\text { analysis (night } \\
\text { and day) }\end{array}$ & $\begin{array}{l}\text { Digital sound } \\
\text { recording }\end{array}$ & LCQ & $\begin{array}{l}\text { Correlation between LCQ total and } \\
\text { log count total: } r=-0.55(95 \% \text { CI } \\
0.383-0.682) \\
\text { Daytime } r=-0.54 \\
(95 \% \text { CI }-0.67 \text { to }-0.371) \\
\text { Nighttime } r=-0.39 \\
(95 \% \text { CI }-0.55 \text { to }-0.19)\end{array}$ \\
\hline $\begin{array}{l}\text { Kelsall, } \\
2008[33]\end{array}$ & 70 & $\begin{array}{l}\text { Median }(24 \mathrm{~h}) \text { : } \\
12.2 \text { coughs } / \mathrm{h} \\
(\text { IQR } 6.8-18.1)\end{array}$ & $\begin{array}{l}\text { Patients with } \\
\text { unexplained } \\
\text { chronic cough }\end{array}$ & $\begin{array}{l}\text { 24-hour } \\
\text { recording }\end{array}$ & $\begin{array}{l}\text { Digital sound } \\
\text { recording: } \\
\text { Cough explosive phase } \\
\text { Cough seconds } \\
\text { Cough episodes }\end{array}$ & LCQ & $\begin{array}{l}\text { Correlation between LCQ total and } \\
\text { explosive phase: } \\
\mathrm{r}=-0.53 \text { ( } 95 \% \text { CI }-0.370 \text { to }-0.659) \\
\text { Correlation between LCQ total and } \\
\text { cough seconds: } \\
r=-0.53 \text { ( } 95 \% \text { CI }-0.69 \text { to }-0.37) \\
\text { Correlation between LCQ total and } \\
\text { cough episode: } \\
r=-0.46(95 \% \text { CI }-0.287 \text { to }-0.604)\end{array}$ \\
\hline $\begin{array}{l}\text { Marsden, } \\
2008[44]\end{array}$ & 53 & $\begin{array}{l}\text { Median: } 2.6 \\
\text { coughs/h }\end{array}$ & $\begin{array}{l}\text { Asthmatic } \\
\text { patients }\end{array}$ & $\begin{array}{l}\text { Ambulatory } \\
\text { recording } \\
\text { for } 24 \mathrm{~h}\end{array}$ & $\begin{array}{l}\text { Numbers of seconds } \\
\text { with } 1 \text { or more explo- } \\
\text { sive cough sounds }\end{array}$ & LCQ & $\begin{array}{l}\text { Correlation between LCQ total and } \\
\text { cough seconds: } \\
r=-0.54(95 \% \text { CI }-0.707 \text { to }-0.316)\end{array}$ \\
\hline
\end{tabular}




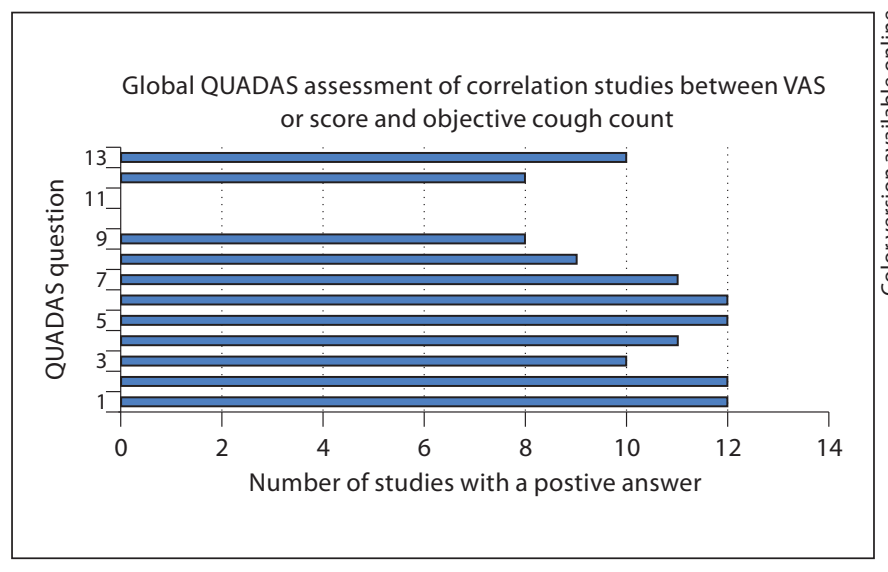

Fig. 4. Global quality of included studies on the comparison between subjective scoring and objective cough count. Number of studies fulfilling each QUADAS criteria.

impact on the patient's quality of life even though other elements are also likely to influence the quality-of-life scores. Further studies could usefully explore the weights of different factors.

\section{Recommendations for the Researcher}

Few studies assessing the effects of cough treatments have objectively measured cough frequency or its repercussions on the quality of life of patients. Clinical trials using validated cough evaluation criteria are required. Different types of measurements could reflect different aspects of cough severity, although the close correlation found between cough frequency and scores on the LCQ suggest that the different aspects may be linked (e.g. cough frequency may influence quality of life). Outcomes should be chosen to be congruent with the objective of the study. Aiming to improve the patients' quality of life is presumably the main objective of symptomatic prescriptions. Quality-of-life questionnaires should probably be used as primary outcome measures in trials of cough suppressants. There are 2 validated instruments for use in adults (LCQ [25] and CQLQ [26]) and 1 for use in children [27]. If cough frequency can be considered an indicator of disease severity, it can be used to monitor the evolution of the disease in terms of the treatment. The LifeShirt, the LCM, and the LR102 seem promising in this respect but require broader validation before their widespread use in clinical trials can be recommended.

\section{Recommendations for the Clinician}

The diagnostic significance of cough rhythm, as well as its nature, frequency, and intensity, is still unclear, and further research on this matter is necessary to determine whether cough pattern monitoring (e.g. characteristic of cough or time occurrence) has a place in clinical practice. Cough frequency monitoring may help to identify predisposing environmental factors [46, 47]. It could also help to objectively evaluate response to treatment, which is an element in the diagnostic work-up of certain cases of cough.

Quality-of-life scores may be useful in the evaluation of chronic cough and may thus direct therapeutic decisions and help the clinician to monitor the evolution of the cough. These questionnaires could also be useful in directing clinicians to particular areas in the patient's quality of life that are affected by the cough (i.e. physical, psychological, or social domains) and thus allow them to provide more appropriate care. Although not currently validated, VDS and VAS may be valuable precisely because they do not correlate with more objective measurements. This may encourage clinicians to investigate the factors that influence the patient's perception of his/her symptoms, disentangling the factors that are directly linked to the objective severity of the cough from other factors, such as mood and anxiety, that should be addressed accordingly. This, in turn, may lead to a reduction in the inappropriate use of cough suppressants.

\section{Acknowledgements}

The authors would like to thank the members of Sophie Leconte's PhD supervising committee for their insightful comments and suggestions regarding cough outcomes.

References

$\checkmark 1$ Okkes IM, Oskam SK, Lamberts H: The probability of specific diagnoses for patients presenting with common symptoms to Dutch family physicians. J Fam Pract 2002; 51:31-36.

2 Irwin RS, Curley FJ, French CL: Chronic cough: the spectrum and frequency of causes, key components of the diagnostic evaluation, and outcome of specific therapy. Am Rev Respir Dis 1990;141:640-647.

-3 Fuller P, Picciotto A, Davies M, McKenzie SA: Cough and sleep in inner-city children. Eur Respir J 1998;12:426-431.

4 Eccles R, Morris S, Jawad M: Lack of effect of codeine in the treatment of cough associated with acute upper respiratory tract infection. J Clin Pharm Ther 1992;17:175-180. 
5 Eccles R: The powerful placebo in cough studies? Pulm Pharmacol Ther 2002;15:303308.

6 Schroeder K, Fahey T: Should we advise parents to administer over the counter cough medicines for acute cough? Systematic review of randomised controlled trials. Arch Dis Child 2002;86:170-175.

-7 Paul IM, Yoder KE, Crowell KR, Shaffer ML, McMillan HS, Carlson LC, et al: Effect of dextromethorphan, diphenhydramine, and placebo on nocturnal cough and sleep quality for coughing children and their parents. Pediatrics 2004;114:e85-e90.

-8 Leconte S, Paulus D, Degryse J: Prolonged cough in children: a summary of the Belgian primary care clinical guideline. Prim Care Respir J 2008;17:206-211.

-9 Elasy TA, Gaddy G: Measuring subjective outcomes: rethinking reliability and validity. J Gen Intern Med 1998;13:757-761.

10 Smith J, Owen E, Earis J, Woodcock A: Effect of codeine on objective measurement of cough in chronic obstructive pulmonary disease. J Allergy Clin Immunol 2006;117: 831-835.

11 Whiting PF, Weswood ME, Rutjes AW, Reitsma JB, Bossuyt PN, Kleijnen J: Evaluation of QUADAS, a tool for the quality assessment of diagnostic accuracy studies. BMC Med Res Methodol 2006;6:9.

12 Matos S, Birring SS, Pavord ID, Evans DH: Detection of cough signals in continuous audio recordings using hidden Markov models. IEEE Trans Biomed Eng 2006;53:1078-1083.

13 Birring SS, Fleming T, Matos S, Raj AA, Evans DH, Pavord ID: The Leicester Cough Monitor: preliminary validation of an automated cough detection system in chronic cough. Eur Respir J 2008;31:1013-1018.

14 Smith JA, Earis JE, Woodcock AA: Establishing a gold standard for manual cough counting: video versus digital audio recordings. Cough 2006;2:6.

15 Barry SJ, Dane AD, Morice AH, Walmsley $\mathrm{AD}$ : The automatic recognition and counting of cough. Cough 2006;2:8.

- 16 Paul IM, Wai K, Jewell SJ, Shaffer ML, Varadan VV: Evaluation of a new self-contained, ambulatory, objective cough monitor. Cough 2006;2:7.

17 Chang AB, Newman RG, Phelan PD, Robertson CF: A new use for an old Holter monitor: an ambulatory cough meter. Eur Respir J 1997; 10:1637-1639.

18 Munyard P, Busst C, Logan-Sinclair R, Bush A: A new device for ambulatory cough recording. Pediatr Pulmonol 1994;18:178-186.

- 19 Hamutcu R, Francis J, Karakoc F, Bush A: Objective monitoring of cough in children with cystic fibrosis. Pediatr Pulmonol 2002; 34:331-335.

20 Corrigan DL, Paton JY: Pilot study of objective cough monitoring in infants. Pediatr Pulmonol 2003;35:350-357.

21 Coyle MA, Keenan DB, Henderson LS, Watkins ML, Haumann BK, Mayleben DW, et al:
Evaluation of an ambulatory system for the quantification of cough frequency in patients with chronic obstructive pulmonary disease. Cough 2005;1:3.

22 Huisman AN, Wu MZ, Uil SM, van den Berg JW: Reliability and validity of a Dutch version of the Leicester Cough Questionnaire. Cough 2007;3:3.

23 Baiardini I, Braido F, Fassio O, Tarantini F, Pasquali M, Tarchino F, et al: A new tool to assess and monitor the burden of chronic cough on quality of life: Chronic Cough Impact Questionnaire. Allergy 2005;60:482488.

24 Braido F, Baiardini I, Tarantini F, Fassio O, Balestracci S, Pasquali $M$, et al: Chronic cough and QoL in allergic and respiratory diseases measured by a new specific validated tool-CCIQ. J Investig Allergol Clin Immunol 2006;16:110-116.

25 Birring SS, Prudon B, Carr AJ, Singh SJ, Morgan MD, Pavord ID: Development of a symptom specific health status measure for patients with chronic cough: Leicester Cough Questionnaire (LCQ). Thorax 2003;58:339343.

26 French CT, Irwin RS, Fletcher KE, Adams TM: Evaluation of a cough-specific qualityof-life questionnaire. Chest 2002;121:11231131.

27 Newcombe PA, Sheffield JK, Juniper EF, Marchant JM, Halsted RA, Masters IB, et al: Development of a parent-proxy quality-oflife chronic cough-specific questionnaire: clinical impact vs. psychometric evaluations. Chest 2008;133:386-395.

28 Kalpaklioglu AF, Kara T, Kurtipek E, Kocyigit P, Ekici A, Ekici M: Evaluation and impact of chronic cough: comparison of specific vs. generic quality-of-life questionnaires. Ann Allergy Asthma Immunol 2005;94:581585.

29 Polley L, Yaman N, Heaney L, Cardwell C, Murtagh E, Ramsey J, et al: Impact of cough across different chronic respiratory diseases: comparison of two cough-specific health-related quality of life questionnaires. Chest 2008;134:295-302.

30 Smith J, Owen E, Earis J, Woodcock A: Cough in COPD: correlation of objective monitoring with cough challenge and subjective assessments. Chest 2006;130:379385.

-31 Decalmer SC, Webster D, Kelsall AA, McGuinness K, Woodcock AA, Smith JA: Chronic cough: how do cough reflex sensitivity and subjective assessments correlate with objective cough counts during ambulatory monitoring? Thorax 2007;62:329-334.

32 Smith JA, Owen EC, Jones AM, Dodd ME, Webb AK, Woodcock A: Objective measurement of cough during pulmonary exacerbations in adults with cystic fibrosis. Thorax 2006;61:425-429.

- 33 Kelsall A, Decalmer S, Webster D, Brown N, McGuinness K, Woodcock A, et al: How to quantify coughing: correlations with quality of life in chronic cough. Eur Respir J 2008;32: 175-179.

-34 Krahnke J, Gentile D, Angelini B, Danzig $\mathrm{M}$, Skoner D: Comparison of objective and subjective measurements of cough frequency in patients with seasonal allergic rhinitis. Ann Allergy Asthma Immunol 2004;93: 259-264.

- 35 Li AM, Tsang TW, Chan DF, Lam HS, So HK, Sung RY, et al: Cough frequency in children with mild asthma correlates with sputum neutrophil count. Thorax 2006;61:747-750.

- 36 Chang AB, Newman RD, Carlin JB, Phelan PD, Robertson CF: Subjective scoring of cough in children: parent-completed vs. child-completed diary cards vs. an objective method. Eur Respir J 1998;11:462-46

37 Chang AB, Phelan PD, Robertson CF, Roberts RG, Sawyer SM: Relation between measurements of cough severity. Arch Dis Child 2003;88:57-60.

38 Zihlif N, Paraskakis E, Lex C, Van de Pohl LA, Bush A:Correlation between cough frequency and airway inflammation in children with primary ciliary dyskinesia. Pediatr Pulmonol 2005;39:551-55

- 39 Hoskyns EW, Thomson A, Decker E, Hutchins A, Simpson H: Effect of controlled release salbutamol on nocturnal cough in asthma. Arch Dis Child 1991;66:1209-1212.

40 Marchant JM, Newcombe PA, Juniper EF, Sheffield JK, Stathis SL, Chang AB: What is the burden of chronic cough for families? Chest 2008;134:303-309.

-41 Torrego A, Haque RA, Nguyen LT, Hew M, Carr DH, Wilson R, et al: Capsaicin cough sensitivity in bronchiectasis. Thorax 2006; 61:706-709.

42 Jeyakumar A, Brickman TM, Haben M: Effectiveness of amitriptyline versus cough suppressants in the treatment of chronic cough resulting from postviral vagal neuropathy. Laryngoscope 2006;116:2108-2112.

43 Birring SS, Matos S, Patel RB, Prudon B, Evans DH, Pavord ID: Cough frequency, cough sensitivity and health status in patients with chronic cough. Respir Med 2006;100:11051109.

44 Marsden PA, Smith JA, Kelsall AA, Owen E, Naylor JR, Webster D, et al: A comparison of objective and subjective measures of cough in asthma. J Allergy Clin Immunol 2008;122: 903-907.

-45 Morice AH, Fontana GA, Belvisi MG, Birring SS, Chung KF, Dicpinigaitis PV, et al: ERS guidelines on the assessment of cough. Eur Respir J 2007;29:1256-1276.

46 Ekici M, Ekici A, Akin A, Altinkaya V, Bulcun E: Chronic airway diseases in adult life and childhood infections. Respiration 2008; 75:55-59.

47 Dong GH, Ma YN, Ding HL, Jin J, Cao Y, Zhao YD, et al: Effects of housing characteristics and home environmental factors on respiratory symptoms of 10,784 elementary school children from northeast china. Respiration 2008;76:82-91. 